\title{
Antioxidant Properties of Probiotic Bacteria
}

\author{
Yang Wang, Yanping Wu, Yuanyuan Wang, Han Xu, Xiaoqiang Mei, Dongyou Yu, Yibing Wang * \\ and Weifen $\mathrm{Li}$ * \\ Key Laboratory of Molecular Animal Nutrition of the Ministry of Education, Institute of Feed Science, \\ College of Animal Sciences, Zhejiang University, Hangzhou 310058, China; 11317017@zju.edu.cn (Y.W.); \\ ypwu0902@163.com (Y.W.); yuanzizju@163.com (Y.W.); 18868107975@139.com (H.X.); \\ 21617067@zju.edu.cn (X.M.); dyyu@zju.edu.cn (D.Y.) \\ * Correspondence: wangyibing1990@126.com (Y.W.); wfli@zju.edu.cn (W.L.); Tel.: +86-138-5812-2675 (Y.W.); \\ +86-571-8898-2108 (W.L.)
}

Received: 7 April 2017; Accepted: 16 May 2017; Published: 19 May 2017

\begin{abstract}
Oxidative stress defines a condition in which the prooxidant-antioxidant balance in the cell is disturbed, resulting in DNA hydroxylation, protein denaturation, lipid peroxidation, and apoptosis, ultimately compromising cells' viability. Probiotics have been known for many beneficial health effects, and the consumption of probiotics alone or in food shows that strain-specific probiotics can present antioxidant activity and reduce damages caused by oxidation. However, the oxidation-resistant ability of probiotics, especially the underling mechanisms, is not properly understood. In this view, there is interest to figure out the antioxidant property of probiotics and summarize the mode of action of probiotic bacteria in antioxidation. Therefore, in the present paper, the antioxidant mechanisms of probiotics have been reviewed in terms of their ability to improve the antioxidant system and their ability to decrease radical generation. Since in recent years, oxidative stress has been associated with an altered gut microbiota, the effects of probiotics on intestinal flora composition are also elaborated.
\end{abstract}

Keywords: oxidative stress; antioxidant; probiotic; signaling pathway; gut microbiota

\section{Introduction}

Oxidative stress refers to elevated intracellular levels of oxygen radicals that cause damage to lipids, proteins, and DNA [1]. Reactive oxygen species (ROS), including superoxide anion radicals, hydroxyl radicals, and hydrogen peroxide, are one of the highly active oxygen free radicals. During evolution, most living organisms possess enzymatic defenses (superoxide dismutase (SOD), glutathione peroxidase (GPx), glutathione reductase (GR)), non-enzymatic antioxidant defenses (glutathione, thioredoxin, Vitamin C, Vitamin E), and repair systems to protect them against oxidative stress [2]. However, these native antioxidant systems are generally not enough to prevent living organisms from oxidative damage. Antioxidant additives using substances that delay or prevent the oxidation of cellular substrates have demonstrated the capacity to protect the human body against oxidative damage. Although several synthetic antioxidants, including butylated hydroxyanisole and butylated hydroxytoluene, have been widely used in retarding lipid oxidation, their safety has recently been questioned due to liver damage and carcinogenicity [3]. Therefore, in recent years, finding safer and natural antioxidants from bio-resources to replace synthetic antioxidants has received a great deal of attention.

Recent studies have led to a renewed interest in probiotics, which are claimed to have health benefits. Probiotics refer to live nonpathogenic microorganisms, which, when administered in adequate amounts, confer microbial balance, particularly in the gastrointestinal tract [4]. Evidence has showed that probiotic bacteria present significant antioxidant abilities both in vivo and in vitro [5-8]. Hence, 
with the increasing popularity of probiotic bacteria, we set out the antioxidant properties of probiotic bacteria and underscore their mode of action in this review.

\section{Reactive Oxygen Species}

Except for anaerobic organisms, oxygen is essential for all animals and plants. Hypoxia occurs when the oxygen concentration is below the normal level, which will lead to injuries and even death. Conversely, oxidative stress will happen if the oxygen concentration is over the normal level. Many factors can force organisms to experience oxidative stress such as cigarettes, herbicides, nitrogen oxides, ozone, radiation, and some metal [9]. ROS, including oxygen ions and peroxides, are the products of normal oxygen consuming metabolic process and are often associated with the principle of oxidative stress [10]. ROS can be both endogenously and exogenously generated. The sources of ROS can be found in Figure 1. Due to their highly reactive nature, ROS can modify other oxygen species, DNA, proteins, or lipids. It is believed that excessive amounts of ROS can cause genomic instability [11], leading to a variety of chronic diseases, including atherosclerosis, arthritis, diabetes, alzheimer's disease, neurodegenerative diseases, and cardiovascular diseases [12-16].

However, it is worth noting that, in addition to oxidative stress, when maintained at proper cellular concentrations, ROS are important for cell signaling roles [17]. In the past decades, researchers have found that ROS could serve as second messengers to regulate biological processes [18]. In 1991, transcription factors of the nuclear factor kappa-light-chain-enhancer of activated B cells of the $(\mathrm{NF} \kappa \mathrm{B}) /$ rel family were first unveiled to be activated by the induction of oxidizing agents or ionizing radiation [19]. Subsequently, some other transcription factors and kinases, including hypoxia-inducible factors (HIFs) and phosphatidylinositol 3-kinase (PI3K), have been discovered to possess redox-sensitive elements that can be regulated by ROS [1,20]. Thus, the two faces of ROS make it difficult to use antioxidants because antioxidants would influence the normal redox biology.

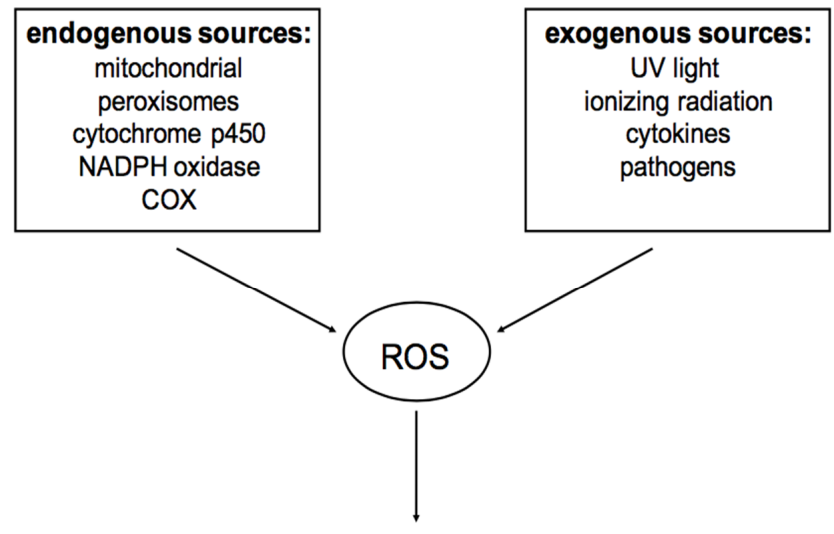

damage to DNA molecules, proteins and lipids

Figure 1. Sources of reactive oxygen species (ROS) (referred to [21]).

\section{Probiotics and Their Roles in Antioxidation}

Previous reviews suggested that probiotics could lower the frequency and duration of diarrhea; stimulate humoral and cellular immunity; prevent cancer; and decrease unfavorable metabolites, including ammonium and procancerogenic enzymes in the colon [2]. Moreover, in recent years, a great number of studies have focused on the impacts of intestinal microbiota on an individual's health status. Probiotics, which are capable of colonizing the intestinal tract, are reported to improve metabolic diseases such as obesity and diabetes through modulating intestinal microorganisms [22-24].

Lactic acid bacteria (LAB) strains are the major representatives of probiotics both in the food and pharmaceutical market [25]. LAB were reported to have positive effects on the treatment and maintenance of ulcerative colitis (UC) [26-28]. They were also associated with the improvement of 
metabolic diseases [23,29]. Additionally, in fishes, Lactobacillus rhamnosus or/and Lactobacillus lactis played a beneficial role in improving the growth, immune system, and oxidative status of sea bream, Pagrus major [30,31]. Probiotic Bifidobacterium is also a very commonly used probiotic bacterium. It was able to promote antitumor immunity [32] and relieve irritable bowel syndrome in women [33]. Bacillus species are preferred in the feed industry because of their stability as spore-forming bacteria and ability to produce a variety of enzymes such as protease, amylase, and lipase [34]. The intestinal microbiota and mucosal immunity of fish could be shaped by Bacillus [35], and the mucosal immunity of chickens could also be improved via Bacillus treatment [36].

In addition to the beneficial effects mentioned above, in recent decades, many findings have shed new light on the understanding of the antioxidant capacity of probiotics. The culture supernatant, intact cells, and intracellular cell-free extracts of Bifidobacterium animalis 01 were found to scavenge hydroxyl radicals and superoxide anion in vitro while enhancing the antioxidase activities of mice in vivo [6]. Further, the oxidative stress in patients with type 2 diabetes can be ameliorated by multispecies probiotics [37]. LAB stains have been studied widely both in animals and the human body. It is revealed that LAB can resist ROS, including peroxide radicals [38], superoxide anions, and hydroxyl radicals [39]. Rats fed high-fat diets supplemented with Lactobacillus plantarum P-8 presented an elevated antioxidant ability, as reflected by curtailing the accumulation of liver lipids and protecting healthy liver function [40]. In humans, Lactobacillus rhamnosus exerted strong antioxidant activity in situations of elevated physical stress. Athletes exposed to oxidative stress might benefit from the ability of Lactobacillus rhamnosus to increase antioxidant levels and neutralize the effects of reactive oxygen species [41].

\section{Modes of Action of Probiotic Bacteria in Antioxidation}

During the past decades, studies have demonstrated that different probiotic bacteria strains could exert antioxidant capacity in different ways. However, few reviews regarding the basis for the antioxidant mechanisms of probiotics have been found. Thus, the following sections provide an overview of the existing knowledge on the oxygen resistant mechanisms of various probiotic strains (Figure 2).

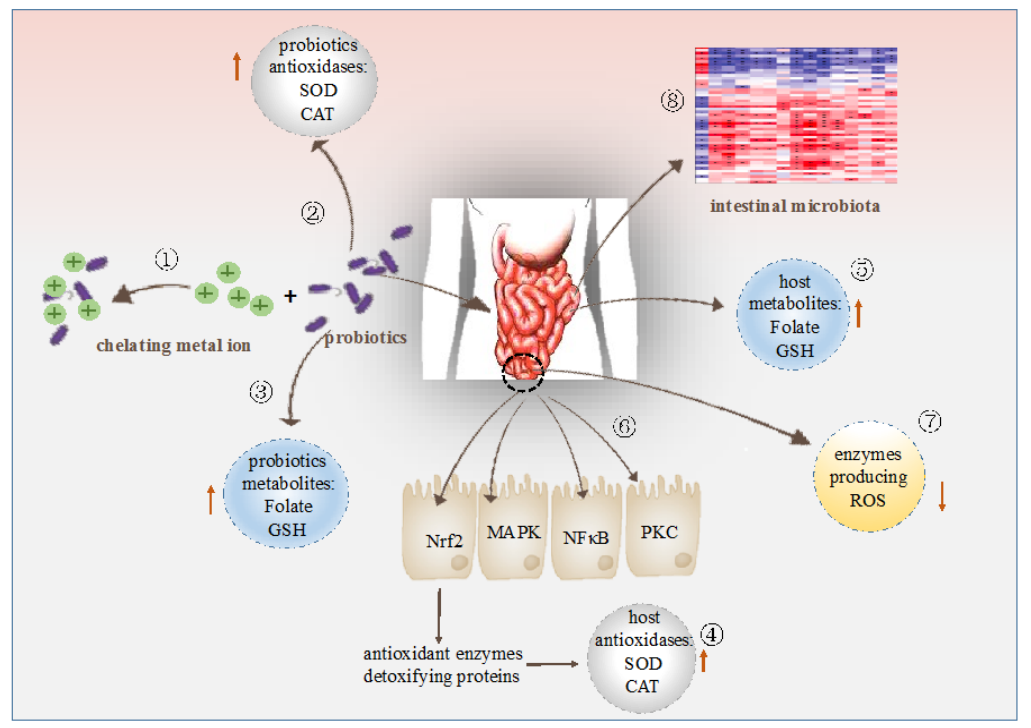

Figure 2. Modulation of antioxidation by probiotics. (1) Probiotics chelate metal ion. (2) Probiotics possess their own antioxidases. (3) Probiotics produce antioxidant metabolites. (4) Probiotics up-regulate antioxidase activities of the host. (5) Probiotics increase levels of antioxidant metabolites of the host. (6) Probiotics regulate signaling pathways. (7) Probiotics down-regulate activities of enzymes producing ROS. (8) Probiotics regulates intestinal microbiota. 


\subsection{Metal Ion Chelating Ability}

Chelators, such as ethylene diamine tetraacetic acid (EDTA), bathophenanthrolinedisulfonic acid (BPS), penicillamine, and desferrioxamine, have been reported to capture metal ions and prevent metal ions from catalyzing the oxidation [42]. The metal ion (ferrous and cupric ions) chelating ability of 19 LAB strains was measured by Lin and Yen in 1999 [5]. The results showed that Streptococcus thermophilus 821 demonstrated the best chelating ability for both $\mathrm{Fe}^{2+}$ and $\mathrm{Cu}^{2+}$. Other strains also showed a chelating ability for either $\mathrm{Fe}^{2+}$ or $\mathrm{Cu}^{2+}$. In addition, another LAB strain, Lactobacillus casei KCTC 3260, was found to possess a high antioxidant ability by chelating $\mathrm{Fe}^{2+}$ or $\mathrm{Cu}^{2+}$, although no detectable SOD activity was observed [43]. Similarly, the intracellular cell-free extract of Lactobacillus helveticus CD6 also showed higher $\mathrm{Fe}^{2+}$ ion chelation [44]. Although the factors responsible for metal ion chelation are not well understood in probiotic bacteria, it is revealed that the transition metal ion can inhibit enzyme-catalyzed phosphate ester displacement reactions and produce peroxyl and alkoxyl radicals by the decomposition of hydroperoxides [45]. Hence, in the opinion of Lin and Yen, the chelating capacity of those probiotic strains may be due to the physiological chelators that exist in the intracellular cell-free extract of probiotics [5].

\subsection{Antioxidant Enzymes System}

Like animals, probiotics also have their own antioxidant enzymatic systems. One of the best known of these enzymes is SOD. Superoxide is one of the most abundant ROS produced by the mitochondria, while SOD catalyzes the breakdown of superoxide into hydrogen peroxide and water and is therefore a central regulator of ROS levels [46]. Bacteria can employ Fe-SOD and Mn-SOD, but mammals utilize both cytoplasmic and extracellular forms of $\mathrm{Cu}, \mathrm{Zn}$-SOD, and mitochondrial Mn-SOD, which is closely related to the bacterial Mn-SOD in evolutionary terms [47]. In the study of Kullisaar and colleagues, Lactobacillus fermentum E-3 and E-18 were able to express Mn-SOD to resist oxidative stress [39]. Although the antioxidant activity of SOD is well-known [48-50], the therapeutic application of SOD is limited, mainly because of its short circulatory half-life, which restricts its bioavailability. In order to address this problem, efforts have been made to find suitable vehicles for SOD. Probiotic bacteria capable of local delivery of SOD open a novel approach to bowel diseases characterized by ROS production. Recently, a study exploring the impact of the engineered Lactobacillus casei BL23 strains producing SOD on mice with Crohn's disease demonstrated that mice receiving engineered strains had a faster recovery of initial weight loss, increased enzymatic activities in the gut, and a lesser extent of intestinal inflammation than the control mice [51].

Catalase (CAT) participates in cellular antioxidant defense by decomposing hydrogen peroxide, thereby preventing the generation of hydroxyl radicals by the Fenton reaction [52]. LAB are generally CAT-negative [53]; however, de LeBlanc and colleagues proved that a CAT-producing Lactococcus slactis could prevent 1,2-dimethylhydrazine-induced colon cancer in mice. Additionally, engineered Lactobacillus casei BL23 strains producing CAT were able to prevent or decrease the severity of intestinal pathologies caused by ROS [54].

Moreover, probiotics can also stimulate the antioxidant system of the host and elevate the activities of antioxidases efficiently. Studies in pigs showed that dietary Lactobacillus fermentum supplementation could increase serum SOD and GPx and enhance hepatic CAT, muscle SOD, and Cu and Zn-SOD compared to the control group [55]. Additionally, the intake of yeast probiotic at different dosages augmented the body weight and GPx activity of chicks [56]. Consistent with this, research in humans have shown an increased erythrocyte SOD and GPx activities as well as total antioxidant status in type 2 diabetic patients receiving yogurt containing Lactobacillus acidophilus La5 and Bifidobacterium lactis Bb12 [57]. Furthermore, our previous in vitro research also implied that Bacillus amyloliquefaciens SC06 elevated CAT and GST gene expressions and the CAT activity in intestinal porcine epithelial cells-1 (IPEC-1) [7]. 


\subsection{Antioxidant Metabolites}

Probiotics can produce various metabolites with antioxidant activity, such as glutathione (GSH), butyrate, and folate. Folate is a vitamin that accepts one-carbon units from donor molecules and is involved in many metabolic pathways. The efficiency of DNA replication, repair, and methylation is affected by folate availability [58]. Due to potentially antioxidant applications, the ability to produce folate has been intensively investigated in multiple probiotic strains from a variety of origins [59]. Evidence showed that the folate-producing Bifidobacteria enhanced the folate status in both rats and human $[60,61]$. In addition, Ahire and colleagues reported that the intracellular cell-free extract of folate producing probiotic Lactobacillus helveticus CD6, demonstrated antioxidant potentials as the intact cell did [44]. GSH, a major cellular non enzymatic antioxidant, eliminates radicals like hydrogen peroxides, hydroxyl radicals, and peroxynitrite mainly via cooperation with selenium dependent glutathione peroxidase [62]. Kullisaar and colleagues found that the two antioxidative Lactobacillus fermentum strains, E-3 and E-18, contained remarkable levels of GSH [39]. Furthermore, for the first time, their research group found a whole GSH system existed in Lactobacillus fermentum ME-3 [63]. Butyrate is a short-chain fatty acid (SCFA) produced by microbiota in the colon and distal small intestine from resistant starch, dietary fiber, and low-digestible polysaccharides by fermentation [64]. The MIYAIRI 588 strain of Clostridium butyricum is a butyrate-producing probiotic. It has been recently shown to induce antioxidases in rats with nonalcoholic fatty liver disease to suppress hepatic oxidative stress [65].

The levels of antioxidant metabolites of the host can also be regulated by probiotics treatment. Folate and vitamin B12 deficiency promoted oxidative stress in adult type 2 diabetes [66]. In the study of Mohammad and colleagues, a randomized nutritional supplementation trial was performed in free-living children of both sexes. Daily consumption of the Lactobacillus acidophilus La1 yoghurt significantly improved the mean levels of plasma folate and vitamin B12 in the studied children compared with the respective baseline data [67], indicating an improved oxidative status. Vitamin B1 is able to rescue cells and animals from oxidative stress [68,69]. In healthy young women, daily consumption of $200 \mathrm{~g}$ of both probiotic and conventional yoghurt for two weeks contributed to the total intake of vitamin B1, which was reflected by increased levels of plasma thiamine [70]. Additionally, the GSH level and biosynthesis of GSH were also enhanced in rats treated with probiotics in order to reduce oxidative stress in experimental acute pancreatitis [71,72].

\subsection{Antioxidant Signaling Pathway Mediated by Probiotic Bacteria}

\subsubsection{Nrf2-Keap1-ARE}

A well-studied system for transducing exogenous stimuli into eukaryotic transcriptional responses is the Nrf2-Keap1-ARE pathway. Nrf2 activation upregulates a series of genes including those involved in xenobiotic and ROS detoxification in order to resist oxidant and electrophilic environmental stressors [73,74]. At low levels of ROS, Nrf2 is bound to its cytoplasmic inhibitor Keap1, which suppresses the activity of Nrf2 by targeting it for constitutive polyubiquitination through a Cullin3-based E3 ligase complex and consequent proteasomal degradation [75]. Keap1 is considered a molecular switch of Nrf2. When cells are attacked by free radicals or nucleophiles, the redox-sensitive cysteine residues of Keap1 react and alter the functional conformation of Keap1, thereby abolishing the inactivation of Nrf2 [76]. Thereafter, Nrf2 translocates to the nucleus and binds to antioxidant response element (ARE) sequences, promoting the transcription of ARE-driven genes such as genes encoding antioxidant enzymes and detoxifying proteins [77-79]. In recent years, both in vivo and in vitro reports have indicated that probiotic bacteria could protect against oxidative stress through regulating the Nrf2-Keap1-ARE pathway. Recently, a high cholesterol diet (hyperlipidemic models, HM) has been employed to construct hyperlipidemic models of male Kunming mice. Hyperlipidemic and normal mice were then treated with Lactobacillus plantarum CAI6, Lactobacillus plantarum SC4, and physiological saline through oral gavage. As expected, the Nrf2 
levels in the liver and kidneys were much higher in mice receiving HM. Moreover, compared with the HM group, liver Nrf2 was significantly increased in mice fed with the HM/CAI6 and HM/SC4 diets [80]. Similarly, the antioxidant and hypolipidemic effects of Lactobacillus plantarum FC225 were investigated in mice fed a high fat diet. The scavenging activities of superoxide anion radicals were enhanced by Lactobacillus plantarum FC225. The flow cytometric analysis of Nrf2 expression and translocation in the hepatocyte of Lactobacillus plantarum FC255-treated mice was markedly promoted, and Lactobacillus plantarum FC225 was further able to prevent a high fat diet-induced inhibition of antioxidant enzymes [81]. As mentioned, Clostridium butyricum MIYAIRI 588 is a butyrate-producing probiotic. Endo and colleagues established the rat nonalcoholic fatty liver disease model with a choline-deficient/L-amino acid (CDAA)-defined-diet [65]. According to their findings, treatment with MIYAIRI 588 elevated hepatic antioxidant enzyme activities in (CDAA)-defined-diet-induced rats via the activation of Nrf2 expressions [65]. Additionally, recent evidence obtained by our research group also demonstrated that probiotic Bacillus amyloliquefaciens SC06 ameliorated the $\mathrm{H}_{2} \mathrm{O}_{2}$-induced IPEC-1 oxidative stress by decreasing ROS levels and regulating Nrf2 expressions [7] (Table 1).

\subsubsection{NFKB}

The first eukaryotic transcription factor shown to respond directly to oxidative stress was NFkB [19]. It is reported that, during inflammation, ROS can mediate the activation of redox-sensitive transcription factor NFKB, and the subsequent expression of inflammatory cytokines [82]. The extracellular polysaccharide from Bacillus sp. strain LBP32 prevented LPS-induced inflammation in RAW 264.7 macrophages by inhibiting NFKB and ROS production [83]. Moreover, probiotic mixture VSL\#3 could inhibit NFKB and induce heat shock proteins in colonic epithelial cells [84] (Table 1).

Table 1. Summary of antioxidant signaling pathways mediated by probiotic bacteria.

\begin{tabular}{|c|c|c|c|}
\hline Species & Signaling Pathway & Host & References \\
\hline Bacillus amyloliquefaciens SC06 & \multirow{4}{*}{ Nrf2-Keap1-ARE } & IPEC-1 cell line & [7] \\
\hline Clostridium butyricum MIYAIRI 588 & & rats & [65] \\
\hline Lactobacillus Plantarum CAI6, SC4 & & mice & [80] \\
\hline Lactobacillus Plantarum FC255 & & mice & [81] \\
\hline Bacillus LBP32 & \multirow{2}{*}{ NFKB } & RAW 264.7 macrophages & [83] \\
\hline VSL\#3 & & colonic epithelial cells & [84] \\
\hline Lactobacillus rhamnosus GG & \multirow{2}{*}{ MAPK } & Caco-2 cell line & [85] \\
\hline Lactobacillus GG-CM & & YAMC cell line & [88] \\
\hline Lactobacillus rhamnosus GG & PKC & Caco-2 cell line & [85] \\
\hline
\end{tabular}

\subsubsection{MAPK}

Mitogen-activated protein kinases (MAPKs) includes four subfamilies, the best characterized of which are the extracellular regulated protein kinases (ERKs), c-jun N-terminal kinase (JNKs), and p38-MAPK; these can be activated by a variety of stimuli [85]. In general, ERKs are mainly involved in anabolic processes such as cell division, growth, and differentiation, whereas JNKs and p38-MAPK are mostly associated with cellular responses to diverse stresses such as UV irradiation and osmotic shock $[86,87]$. Soluble factors of conditioned media from the probiotic Lactobacillus GG (Lactobacillus GG-CM) could induce both heat shock protein (Hsp)25 and Hsp72 in a time- and concentration-dependent manner in young adult mouse colon (YAMC) cells. Tao and colleagues suggested that the pretreatment of cells with Lactobacillus GG-CM alone activated all three MAPKs investigated [88]. Exposure of YAMC cells to inhibitors against p38 and JNK before Lactobacillus GG-CM treatment resulted in the blockade of Hsp72 expression, which confirmed the role for MAPK signaling pathways in the induction of Hsps by Lactobacillus GG-CM in epithelial cells [88]. In addition, Seth and colleagues used the strong oxidizer $\mathrm{H}_{2} \mathrm{O}_{2}$ to induce the disruption of tight junctions and 
barrier function in Caco-2 cell monolayers [85]. In their study, Lactobacillus rhamnosus GG was observed to the produce soluble proteins p40 and p75, which were able to ameliorate the $\mathrm{H}_{2} \mathrm{O}_{2}$-induced epithelial barrier disruption by a MAPK-dependent mechanism [85] (Table 1).

\subsubsection{PKC}

Protein kinase C (PKC) represents a family of phospholipid-dependent ser/thr kinases that are involved in a variety of pathways that regulate cell growth, death, and stress responsiveness [89,90]. Evidence demonstrates that PKC is among a group of cell-signaling molecules that are sensitive targets for redox modification [91]. As aforementioned, besides MAPKs, the attenuation of $\mathrm{H}_{2} \mathrm{O}_{2}$-induced redistribution of tight junction proteins by the aforementioned soluble proteins produced by Lactobacillus rhamnosus GG was abrogated by Ro-32-0432, a PKC inhibitor [85] (Table 1).

\subsection{Regulation of The Enzymes Producing ROS}

Oxidative stress is derived either from an increase in ROS production or decreased levels of ROS-scavenging proteins. Thus, recently many studies have investigated the effects of probiotics on ROS production. ROS are generated by several enzymatic reactions and chemical processes [92]. NADPH oxidase (NOX) complex is considered to be a major source of ROS generation [93-95]. It is now known that there are seven human NOX homologues (NOX1-5, dual oxidase 1 (DUOX1), and DUOX2) that function to purposely produce ROS for a range of host defense and signaling functions [96]. The catalytic subunit of this complex is NOX2. NOX2 does not generate superoxide on its own; rather, stimulating the neutrophil causes the recruitment of cytosolic factors that include p40phox, p47phox , p67phox, and the small GTPase RAC1. These cytosolic factors combine with the membrane-bound NOX2 and $\mathrm{p} 22^{\mathrm{phox}}$ to generate the classic phagocyte response to stimulation known as the respiratory burst [97,98]. Recently, Gómez-Guzmán and colleagues have suggested that probiotics Lactobacillus fermentum CECT5716 and Lactobacillus coryniformis CECT5711 (K8) plus Lactobacillus gasseri CECT5714 (LC9) (1:1) were able to decrease NOX activity and mRNA expressions of NOX-1 as well as NOX-4 in spontaneously hypertensive rats [99]. The oxidative stress of $\mathrm{H}_{2} \mathrm{O}_{2}$-induced IPEC-1 was also shown as decreased NOX activity and $4^{\text {phox }}$ expression by Bacillus amyloliquefaciens SC06 treatment [7].

Cyclo-oxygenase (COX) is a rate-limiting enzyme in prostaglandin biosynthesis and a two-step enzymatic process in which ROS are generated [100]. COX-2 was upregulated in atherosclerotic lesions [101] and catalyzes the production of the majority of vascular prostanoids in human atherosclerotic areas [102]. Down-regulated COX-2 was found in helicobacter pylori-infected mongolian gerbils with a commercial probiotic Lacidofil treatment [103]. Patel and colleagues demonstrated that Lactobacillus acidophilus pretreatment decreased COX-2 expression in catla thymus macrophages compared to Aeromonas hydrophila and co-stimulated macrophages [104].

The cytochrome P450 (CYP) enzymes are important in the oxidative metabolism of xenobiotic agents [105]. Poor coupling of the P450 catalytic cycle leads to continuous production of ROS, which affects signaling pathways and other cellular functions [106]. A few studies have explored the role of probiotics in regulating CYP. With the application of Lactobacillus casei, the expression of the CYP1A1 enzyme was found to be decreased in the proximal part of the jejunum and colon of male rats. Meanwhile, the CYP1A1 mRNA level was also decreased in the distal part of the jejunum, ileum, and caecum [107]. In the study by Sharan, the effects of milk, Dhi, and four probiotic Dahi preparations, namely Acidophilus Dahi, Plantarum Dahi, Acidopholus-plantarum Dahi, and Acidophilus-bifidus Dahi, on CYP and the antioxidase activities of rats was investigated [108]. Feeding Acidophilus Dahi for eight weeks could up-regulate the activities of quinone reductase and glutathione S-transferase in the liver and glutathione S-transferase in the colon. Accompanying this, the activities of CYP1A1, CYP1A2, and CYP1B1 were significantly decreased in the livers of rats fed Acidopholus-plantarum Dahi and Acidopholus-plantarum Dahi or Acidopholus-plantarum Dahi and Acidophilus-bifidus [108]. 


\subsection{Regulation of The Intestinal Microbiota}

\subsubsection{The Intestinal Microbiota Composition}

Infants develop their microbiome at or before birth and by exposure to bacteria through the birth canal or contact with maternal skin in the case of Caesarian born babies [109]. Gut colonization of the newborn begins with facultative anaerobes such as enterobacteria and streptococci and continues with anaerobic genera, including Bifidobacterium, Bacteroides, and Clostridium [110,111]. The gut microbial composition in the newborn undergoes substantial modulation with a number of environmental and genetic factors to ultimately form the commensal intestinal microbiota. Each human adult harbors approximately $10^{14}$ bacteria in the gut, which is about 10 times the number of cells making up the human body [112]. There are at least 400-500 different bacterial species, which can be divided into different strains, highlighting the enormous complexity of this ecosystem [113]. The majority of bacterial species in a healthy human gut is Bacteroidetes (including Clostridia and Bacilli) and Firmicutes (Bacteroides fragilis and Bacteroides thetaiotaomicron) [114]. In contrast, Proteobacteria, Actinobacteria, Fusobacteria, Cyanobacteria, and Verrucomicrobia are less abundant phyla [115]. Moreover, different bacterial groups are enriched at different sites. It is reported that the Bacilli class of the Firmicutes and Actinobacteria is rich in the small intestine, whereas the Bacteroidetes and Lachnospiraceae families of the Firmicutes were more prevalent in the colon [116]. In addition, microbiota composition in the intestinal lumen differs significantly from the microbiota attached and embedded in the mucus layer as well as the microbiota in the immediate proximity of the epithelium [117].

\subsubsection{The Antioxidant Influences of Probiotics by Regulating Microbiota Composition}

Gut microbiota protects its host from pathogens by competitive exclusion, including occupation of attachment sites, consumption of nutrient sources, and production of antimicrobial substances [117]. When the intestinal microbiota is abnormal, harmful bacteria will proliferate excessively, inducing the endotoxin in blood and causing significant oxidative stress. Microbial contact-induced epithelial ROS generation is an extremely conserved phenomenon across phyla. This mechanism is a general mean by which bacterial communities can affect redox homeostatic in the host [118]. Although the functions of probiotics in altering intestinal microbiota composition and gut diseases have been reviewed $[119,120]$, there have been relatively few studies that rigorously characterize the effect of probiotics on antioxidation regarding the intestinal microbiota composition. Probiotics are regular habitants of the gastrointestinal tract of both humans and animals [121,122], and they can regulate the composition of intestinal microbiota and inhibit the excessive proliferation of harmful bacteria, which may contribute to decreased oxidative stress. Lactobacillus and Bifidobacterium, the most common probiotic species, producing lactic acid, acetic acid, and propionic acid, can lower the intestinal $\mathrm{pH}$ and suppress the growth of various pathogenic bacteria to keep the balance of the gut flora $[123,124]$. Lactobacillus rhamnosus GG, which has been shown to secrete a low-molecular-weight compound, can inhibit a broad spectrum of gram-positive, gram-negative, and anaerobic bacteria [125]. Additionally, for specific probiotic strains, the production of various substances such as organic acids, bacteriocins, and biosurfactants, are toxic to pathogenic microorganisms [126]. Moreover, gut microbes influence the metabolism of cells in tissues outside of the intestines, such as liver and adipose tissue, and thereby modulate lipid and glucose homeostasis, as well as systemic inflammation, in the host [127]. Recently, Qiao and colleagues have reported that the alterations of gut microbiota in high-fat diet (HFD)-fed mice was strongly linked to oxidative stress [128]. The changes in intestinal microbiota following HFD could promote metabolic endotoxemia and trigger metabolic disorders, including obesity and oxidative stress [127]. According to the research of Xin and colleagues, Lactobacillus johnsonii BS15 attenuated the HFD-induced oxidative stress of mice and change the Firmicutes / Bacteroidetes of gut microbiota [129]. Furthermore, supplementation of Lactobacillus curvatus HY7601 and Lactobacillus plantarum KY1032 in HFD-fed obese mice also induced gut microbial changes [130]. Everard and colleagues found that Saccharomyces boulardii reduce inflammation and fat 
mass in obese and type 2 diabetic mice. The effects of Saccharomyces boulardii on the host metabolism were associated with the dramatic changes in the gut microbial composition [131]. In a very recent study, in parallel with the improved intestinal endotoxemia, probiotic supplementation consisting of Bifidobacterium infantis, Lactobacillus acidopilus, and Bacillus cereus, increased the levels of these anaerobic bacteria but decreased the abundance of Escherichia coli and Enterococcus in the fecal sample of rats fed a high-sugar and high-fat diet [132].

\section{Conclusions}

The past few years have witnessed a tremendous growth in our knowledge concerning the beneficial effects of probiotics, especially those important in mediating responses to oxidative stress. However, the mechanisms of antioxidant action have not been properly understood. In this review, we summarize that probiotics may modulate the redox status of the host via their metal ion chelating ability, antioxidant systems, regulating signaling pathways, enzyme producing ROS, and intestinal microbiota. However, there are still many unsolved questions. It is controversial whether those in vitro results from animal experiments are transferable to humans. As most of the probiotics are incapable of colonizing the gut and are eliminated shortly after consumption [133], it is not clear what would be the outcome of prolonged administration. Thus, the complete picture of the interaction between probiotics and antioxidant capacity should be further investigated and come into view in the near future.

Acknowledgments: This study is supported by the National Natural Science Foundation of China (No. 31672460), the National High-Tech R\&D Program (863) of China (No. 2013AA102803D), the National Natural Science Foundation of China (No. 31472128), and the Major Science and Technology Project of Zhejiang Province (No. 2006C12086), China.

Author Contributions: All authors contributed substantially to the conception and design of the manuscript. Yang Wang wrote the first draft of the manuscript. All authors contributed to revisions and approved the final version.

Conflicts of Interest: The authors declare no conflict of interest.

\section{References}

1. Schieber, M.; Chandel, N.S. ROS function in redox signaling and oxidative stress. Curr. Biol. 2014, 24, R453-R462. [CrossRef] [PubMed]

2. Mishra, V.; Shah, C.; Mokashe, N.; Chavan, R.; Yadav, H.; Prajapati, J. Probiotics as potential antioxidants: A systematic review. J. Agric. Food Chem. 2015, 63, 3615-3626. [CrossRef] [PubMed]

3. Luo, D.; Fang, B. Structural identification of ginseng polysaccharides and testing of their antioxidant activities. Carbohydr. Polym. 2008, 72, 376-381. [CrossRef]

4. Williams, N.T. Probiotics. Am. J. Health Syst. Pharm. 2010, 67, 449-458. [CrossRef] [PubMed]

5. Lin, M.Y.; Yen, C.L. Antioxidative ability of lactic acid bacteria. J. Agric. Food Chem. 1999, 47, 1460-1466. [CrossRef] [PubMed]

6. Shen, Q.; Shang, N.; Li, P. In vitro and in vivo antioxidant activity of Bifidobacterium animalis 01 isolated from centenarians. Curr. Microbiol. 2011, 62, 1097-1103. [CrossRef] [PubMed]

7. Wang, Y.; Wu, Y.; Wang, Y.; Fu, A.; Gong, L.; Li, W.; Li, Y. Bacillus amyloliquefaciens SC06 alleviates the oxidative stress of IPEC-1 via modulating Nrf2/Keap1 signaling pathway and decreasing ROS production. Appl. Microbiol. Biotechnol. 2016, 101, 1-12. [CrossRef] [PubMed]

8. Persichetti, E.; De Michele, A.; Codini, M.; Traina, G. Antioxidative capacity of Lactobacillus fermentum LF31 evaluated in vitro by oxygen radical absorbance capacity assay. Nutrition 2014, 30, 936-938. [CrossRef] [PubMed]

9. Halliwell, B.; Cross, C.E. Oxygen-derived species: Their relation to human disease and environmental stress. Environ. Health Perspect. 1994, 102, 5. [CrossRef] [PubMed]

10. Cross, C.E.; Halliwell, B.; Borish, E.T.; Pryor, W.A.; Ames, B.N.; Saul, R.L.; McCord, J.M.; Harman, D. Oxygen radicals and human disease. Ann. Int. Med. 1987, 107, 526-545. [CrossRef] [PubMed]

11. Ames, B.N.; Shigenaga, M.K.; Hagen, T.M. Oxidants, antioxidants, and the degenerative diseases of aging. Proc. Natl. Acad. Sci. USA 1993, 90, 7915-7922. [CrossRef] [PubMed] 
12. Eftekharzadeh, B.; Maghsoudi, N.; Khodagholi, F. Stabilization of transcription factor Nrf2 by tBHQ prevents oxidative stress-induced amyloid $\beta$ formation in NT2N neurons. Biochimie 2010, 92, 245-253. [CrossRef] [PubMed]

13. Harrison, D.; Griendling, K.K.; Landmesser, U.; Hornig, B.; Drexler, H. Role of oxidative stress in atherosclerosis. Am. J. Cardiol. 2003, 91, 7-11. [CrossRef]

14. Ostrakhovitch, E.A.; Afanas'ev, I.B. Oxidative stress in rheumatoid arthritis leukocytes: Suppression by rutin and other antioxidants and chelators. Biochem. Pharmacol. 2001, 62, 743-746. [CrossRef]

15. Griendling, K.K.; FitzGerald, G.A. Oxidative stress and cardiovascular injury part I: Basic mechanisms and in vivo monitoring of ROS. Circulation 2003, 108, 1912-1916. [CrossRef] [PubMed]

16. Ceriello, A.; Motz, E. Is oxidative stress the pathogenic mechanism underlying insulin resistance, diabetes, and cardiovascular disease? The common soil hypothesis revisited. Arterioscler. Thromb. Vasc. Biol. 2004, 24, 816-823. [CrossRef] [PubMed]

17. Morrell, C.N. Reactive Oxygen Species. Circ. Res. 2008, 103, 571-572. [CrossRef] [PubMed]

18. Finkel, T. Signal transduction by reactive oxygen species. J. Cell Biol. 2011, 194, 7-15. [CrossRef] [PubMed]

19. Schreck, R.; Rieber, P.; Baeuerle, P.A. Reactive oxygen intermediates as apparently widely used messengers in the activation of the NF-kappa B transcription factor and HIV-1. EMBO J. 1991, 10, 2247-2258. [PubMed]

20. Hensley, K.; Robinson, K.A.; Gabbita, S.P.; Salsman, S.; Floyd, R.A. Reactive oxygen species, cell signaling, and cell injury. Free Radic. Biol. Med. 2000, 28, 1456-1462. [CrossRef]

21. Waris, G.; Ahsan, H. Reactive oxygen species: Role in the development of cancer and various chronic conditions. J. Carcinog. 2006, 5, 14. [CrossRef] [PubMed]

22. Wang, J.; Tang, H.; Zhang, C.; Zhao, Y.; Derrien, M.; Rocher, E.; van-Hylckama Vlieg, J.E.; Strissel, K.; Zhao, L.; Obin, M.; et al. Modulation of gut microbiota during probiotic-mediated attenuation of metabolic syndrome in high fat diet-fed mice. ISME J. 2015, 9, 1-15. [CrossRef] [PubMed]

23. Rad, A.H.; Sahhaf, F.; Hassanalilou, T.; Ejtahed, H.S.; Motayagheni, N.; Soroush, A.R.; Javadi, M.; Mortazavian, A.M.; Khalili, L. Diabetes management by probiotics: Current knowledge and future perspectives. Curr. Diabetes Rev. 2016. [CrossRef]

24. Gomes, A.C.; Bueno, A.A.; de Souza, R.G.; Mota, J.F. Gut microbiota, probiotics and diabetes. Nutr. J. 2014, 13, 60. [CrossRef] [PubMed]

25. Holzapfel, W.H.; Schillinger, U. Introduction to pre-and probiotics. Food Res. Int. 2002, 35, 109-116. [CrossRef]

26. Zocco, M.A.; dal Verme, L.Z.; Cremonini, F.; Piscaglia, A.C.; Nista, E.C.; Candelli, M.; Novi, M.; Rigante, D.; Cazzato, I.A.; Ojetti, V.; et al. Efficacy of Lactobacillus GG in maintaining remission of ulcerative colitis. Aliment. Pharmacol. Ther. 2006, 23, 1567-1574. [CrossRef] [PubMed]

27. Saez-Lara, M.J.; Gomez-Llorente, C.; Plaza-Diaz, J.; Gil, A. The role of probiotic lactic acid bacteria and bifidobacteria in the prevention and treatment of inflammatory bowel disease and other related diseases: A systematic review of randomized human clinical trials. BioMed Res. Int. 2015, 2015. [CrossRef] [PubMed]

28. Liu, Y.W.; Su, Y.W.; Ong, W.K.; Cheng, T.H.; Tsai, Y.C. Oral administration of Lactobacillus plantarum K68 ameliorates DSS-induced ulcerative colitis in BALB/c mice via the anti-inflammatory and immunomodulatory activities. Int. Immunopharmacol. 2011, 11, 2159-2166. [CrossRef] [PubMed]

29. Huang, H.Y.; Korivi, M.; Tsai, C.H.; Yang, J.H.; Tsai, Y.C. Supplementation of lactobacillus plantarum K68 and fruit-vegetable ferment along with high fat-fructose diet attenuates metabolic syndrome in rats with insulin resistance. Evid. Based Complement. Altern. Med. 2013, 2013. [CrossRef] [PubMed]

30. Dawood, M.A.; Koshio, S.; Ishikawa, M.; Yokoyama, S.; El Basuini, M.F.; Hossain, M.S.; Nhu, T.H.; Dossou, S.; Moss, A.S. Effects of dietary supplementation of Lactobacillus rhamnosus or/and Lactococcus lactis on the growth, gut microbiota and immune responses of red sea bream, Pagrus major. Fish Shellfish Immunol. 2016, 49, 275-285. [CrossRef] [PubMed]

31. Dawood, M.A.; Koshio, S.; Ishikawa, M.; El-Sabagh, M.; Esteban, M.A.; Zaineldin, A.I. Probiotics as an environment-friendly approach to enhance red sea bream, Pagrus major growth, immune response and oxidative status. Fish Shellfish Immunol. 2016, 57, 170-178. [CrossRef] [PubMed]

32. Sivan, A.; Corrales, L.; Hubert, N.; Williams, J.B.; Aquino-Michaels, K.; Earley, Z.M.; Benyamin, F.W.; Lei, Y.M.; Jabri, B.; Alegre, M.L.; et al. Commensal Bifidobacterium promotes antitumor immunity and facilitates anti-PD-L1 efficacy. Science 2015, 350, 1084-1089. [CrossRef] [PubMed] 
33. Whorwell, P.J.; Altringer, L.; Morel, J.; Bond, Y.; Charbonneau, D.; O'Mahony, L.; Kiely, B.; Shanahan, F.; Quigley, E.M. Efficacy of an encapsulated probiotic Bifidobacterium infantis 35624 in women with irritable bowel syndrome. Am. J. Gastroenterol. 2006, 101, 1581-1590. [CrossRef] [PubMed]

34. Lei, K.; Li, Y.L.; Yu, D.Y.; Rajput, I.R.; Li, W.F. Influence of dietary inclusion of Bacillus licheniformis on laying performance, egg quality, antioxidant enzyme activities, and intestinal barrier function of laying hens. Poult. Sci. 2013, 92, 2389-2395. [CrossRef] [PubMed]

35. Yang, H.L.; Xia, H.Q.; Ye, Y.D.; Zou, W.C.; Sun, Y.Z. Probiotic Bacillus pumilus SE5 shapes the intestinal microbiota and mucosal immunity in grouper Epinephelus coioides. Dis. Aquat. Org. 2014, 111, 119-127. [CrossRef] [PubMed]

36. Rajput, I.R.; Li, L.Y.; Xin, X.; Wu, B.B.; Juan, Z.L.; Cui, Z.W.; Yu, D.Y.; Li, W.F. Effect of Saccharomyces boulardii and Bacillus subtilis B10 on intestinal ultrastructure modulation and mucosal immunity development mechanism in broiler chickens. Poult. Sci. 2013, 92, 956-965. [CrossRef] [PubMed]

37. Asemi, Z.; Zare, Z.; Shakeri, H.; Sabihi, S.S.; Esmaillzadeh, A. Effect of multispecies probiotic supplements on metabolic profiles, hs-CRP, and oxidative stress in patients with type 2 diabetes. Ann. Nutr. Metab. 2013, 63, 1-9. [CrossRef] [PubMed]

38. Stecchini, M.L.; Del Torre, M.; Munari, M. Determination of peroxy radical-scavenging of lactic acid bacteria. Int. J. Food Microbiol. 2001, 64, 183-188. [CrossRef]

39. Kullisaar, T.; Zilmer, M.; Mikelsaar, M.; Vihalemm, T.; Annuk, H.; Kairane, C.; Kilk, A. Two antioxidative lactobacilli strains as promising probiotics. Int. J. Food Microbial. 2002, 72, 215-224. [CrossRef]

40. Bao, Y.; Wang, Z.; Zhang, Y.; Zhang, J.; Wang, L.; Dong, X.; Su, F.; Yao, G.; Wang, S.; Zhang, H. Effect of Lactobacillus plantarum P-8 on lipid metabolism in hyperlipidemic rat model. Eur. J. Lipid Sci. Technol. 2012, 114, 1230-1236. [CrossRef]

41. Martarelli, D.; Verdenelli, M.C.; Scuri, S.; Cocchioni, M.; Silvi, S.; Cecchini, C.; Pompei, P. Effect of a probiotic intake on oxidant and antioxidant parameters in plasma of athletes during intense exercise training. Curr. Microbiol. 2011, 62, 1689-1696. [CrossRef] [PubMed]

42. Gutteridge, J.M.C.; Richmond, R.; Halliwell, B. Inhibition of the iron-catalyzed formation of hydroxyl radicals from superoxide of lipid peroxidation by desferrioxamine. Biochem. J. 1979, 184, 469-472. [CrossRef] [PubMed]

43. Lee, J.; Hwang, K.T.; Chung, M.Y.; Cho, D.; Park, C. Resistance of Lactobacillus casei KCTC 3260 to reactive oxygen species (ROS): Role for a metal ion chelating effect. J. Food Sci. 2005, 70, m388-m391. [CrossRef]

44. Ahire, J.J.; Mokashe, N.U.; Patil, H.J.; Chaudhari, B.L. Antioxidative potential of folate producing probiotic Lactobacillus helveticus CD6. J. Food Sci. Technol. 2013, 50, 26-34. [CrossRef] [PubMed]

45. Halliwell, B.; Murcia, H.A.; Chirico, S.; Aruoma, O.I. Free radicals and antioxidants in food and in vivo: What they do and how they work. Crit. Rev. Food Sci. Nutr. 1995, 35, 7-20. [CrossRef] [PubMed]

46. Landis, G.N.; Tower, J. Superoxide dismutase evolution and life span regulation. Mech. Ageing Dev. 2005, 126, 365-379. [CrossRef] [PubMed]

47. Davies, K.J.A. Oxidative stress, antioxidant defenses, and damage removal, repair, and replacement systems. IUBMB Life 2000, 50, 279-289. [CrossRef] [PubMed]

48. Koc, M.; Taysi, S.; Buyukokuroglu, M.E.; Bakan, N. Melatonin protects rat liver against irradiation-induced oxidative injury. J. Radiat. Res. 2003, 44, 211-215. [CrossRef] [PubMed]

49. Seguí, J.; Gironella, M.; Sans, M.; Granell, S.; Gil, F.; Gimeno, M.; Coronel, P.; Pique, J.; Panes, J. Superoxide dismutase ameliorates TNBS-induced colitis by reducing oxidative stress, adhesion molecule expression, and leukocyte recruitment into the inflamed intestine. J. Leukoc. Biol. 2004, 76, 537-544. [CrossRef] [PubMed]

50. Mollà, M.; Gironella, M.; Salas, A.; Closa, D.; Biete, A.; Gimeno, M.; Coronel, P.; Pique, J.M.; Panes, J. Protective effect of superoxide dismutase in radiation-induced intestinal inflammation. Int. J. Radiat. Oncol. Biol. Phys. 2005, 61, 1159-1166. [CrossRef] [PubMed]

51. LeBlanc, J.G.; Del Carmen, S.; Miyoshi, A.; Azevedo, V.; Sesma, F.; Langella, P.; Bermudez-Humaran, L.; Watterlot, L.; Perdigon, G. Use of superoxide dismutase and catalase producing lactic acid bacteria in TNBS induced Crohn's disease in mice. J. Biotechnol. 2011, 151, 287-293. [CrossRef] [PubMed]

52. Ho, Y.S.; Xiong, Y.; Ma, W.; Spector, A.; Ho, D. Mice lacking catalase develop normally but show differential sensitivity to oxidant tissue injury. J. Biol. Chem. 2004, 279, 32804-32812. [CrossRef] [PubMed] 
53. Spyropoulos, B.G.; Misiakos, E.P.; Fotiadis, C.; Stoidis, C. Antioxidant properties of probiotics and their protective effects in the pathogenesis of radiation-induced enteritis and colitis. Dig. Dis. Sci. 2011, 56, 285-294. [CrossRef] [PubMed]

54. De LeBlanc, A.M.; LeBlanc, J.G.; Perdigon, G.; Miyoshi, A.; Langella, P.; Azevedo, V.; Sesma, F. Oral administration of a catalase-producing Lactococcus lactis can prevent a chemically induced colon cancer in mice. J. Med. Microbiol. 2008, 57, 100-105. [CrossRef] [PubMed]

55. Wang, A.N.; Yi, X.W.; Yu, H.F.; Dong, B.; Qiao, S.Y. Free radical scavenging activity of Lactobacillus fermentum in vitro and its antioxidative effect on growing-finishing pigs. J. Appl. Microbiol. 2009, 107, 1140-1148. [CrossRef] [PubMed]

56. Aluwong, T.; Kawu, M.; Raji, M.; Dzenda, T.; Govwang, F.; Sinkalu, V.; Ayo, J. Effect of yeast probiotic on growth, antioxidant enzyme activities and malondialdehyde concentration of broiler chickens. Antioxidants 2013, 2, 326-339. [CrossRef] [PubMed]

57. Ejtahed, H.S.; Mohtadi-Nia, J.; Homayouni-Rad, A.; Niafar, M.; Asghari-Jafarabadi, M.; Mofid, V. Probiotic yogurt improves antioxidant status in type 2 diabetic patients. Nutrition 2012, 28, 539-543. [CrossRef] [PubMed]

58. Pompei, A.; Cordisco, L.; Amaretti, A.; Zanoni, S.; Matteuzzi, D.; Rossi, M. Folate production by bifidobacteria as a potential probiotic property. Appl. Environ. Microbiol. 2007, 73, 179-185. [CrossRef] [PubMed]

59. Rossi, M.; Amaretti, A.; Raimondi, S. Folate production by probiotic bacteria. Nutrients 2011, 3, 118-134. [CrossRef] [PubMed]

60. Pompei, A.; Cordisco, L.; Amaretti, A.; Zanoni, S.; Raimondi, S.; Matteuzzi, D.; Rossi, M. Administration of folate-producing bifidobacteria enhances folate status in Wistar rats. J. Nutr. 2007, 137, 2742-2746. [PubMed]

61. Strozzi, G.P.; Mogna, L. Quantification of folic acid in human feces after administration of Bifidobacterium probiotic strains. J. Clin. Gastroenterol. 2008, 42, S179-S184. [CrossRef] [PubMed]

62. Zilmer, M.; Soomets, U.; Rehema, A.; Langel, U. The glutathione system as an attractive therapeutic target. Drug Des. Rev. 2005, 2, 121-127. [CrossRef]

63. Kullisaar, T.; Songisepp, E.; Aunapuu, M.; Kilk, K.; Arend, A.; Mikelsaar, M.; Rehema, A.; Zilmer, M. Complete glutathione system in probiotic Lactobacillus fermentum ME-3. Prikl. Biokhimiia Mikrobiol. 2010, 46, 481-486. [CrossRef]

64. Kau, A.L.; Ahern, P.P.; Griffin, N.W.; Goodman, A.L.; Gordon, J.I. Human nutrition, the gut microbiome and the immune system. Nature 2011, 474, 327-336. [CrossRef] [PubMed]

65. Endo, H.; Niioka, M.; Kobayashi, N.; Tanaka, M.; Watanabe, T. Butyrate-producing probiotics reduce nonalcoholic fatty liver disease progression in rats: New insight into the probiotics for the gut-liver axis. PLoS ONE 2013, 8, e63388. [CrossRef] [PubMed]

66. Al-Maskari, M.Y.; Waly, M.I.; Ali, A.; Al-Shuaibi, Y.S.; Ouhtit, A. Folate and vitamin B12 deficiency and hyperhomocysteinemia promote oxidative stress in adult type 2 diabetes. Nutrition 2012, 28, e23-e26. [CrossRef] [PubMed]

67. Mohammad, M.A.; Molloy, A.; Scott, J.; Hussein, L. Plasma cobalamin and folate and their metabolic markers methylmalonic acid and total homocysteine among Egyptian children before and after nutritional supplementation with the probiotic bacteria Lactobacillus acidophilus in yoghurt matrix. Int. J. Food Sci. Nutr. 2006, 57, 470-480. [CrossRef] [PubMed]

68. Nandi, D.; Patra, R.C.; Swarup, D. Effect of cysteine, methionine, ascorbic acid and thiamine on arsenic-induced oxidative stress and biochemical alterations in rats. Toxicology 2005, 211, 26-35. [CrossRef] [PubMed]

69. Mehta, R.; Dedina, L.; O’Brien, P.J. Rescuing hepatocytes from iron-catalyzed oxidative stress using vitamins B1 and B6. Toxicol. In Vitro 2011, 25, 1114-1122. [CrossRef] [PubMed]

70. Fabian, E.; Majchrzak, D.; Dieminger, B.; Meyer, E.; Elmadfa, I. Influence of probiotic and conventional yoghurt on the status of vitamins B1, B2 and B6 in young healthy women. Ann. Nutr. Metab. 2008, 52, $29-36$. [CrossRef] [PubMed]

71. Lutgendorff, F.; Trulsson, L.M.; van Minnen, L.P.; Rijkers, G.T.; Timmerman, H.M.; Franzen, L.E.; Gooszen, H.G.; Akkermans, L.M.; Soderholm, J.D.; Sandstrom, P.A. Probiotics enhance pancreatic glutathione biosynthesis and reduce oxidative stress in experimental acute pancreatitis. Am. J. Physiol. Gastrointest. Liver Physiol. 2008, 295, G1111-G1121. [CrossRef] [PubMed] 
72. Lutgendorff, F.; Nijmeijer, R.M.; Sandström, P.A.; Trulsson, L.M.; Magnusson, K.E.; Timmerman, H.M.; van Minnen, L.P.; Rijkers, G.T.; Gooszen, H.G.; Akkermans, L.M.; et al. Probiotics prevent intestinal barrier dysfunction in acute pancreatitis in rats via induction of ileal mucosal glutathione biosynthesis. PLoS ONE 2009, 4, e4512. [CrossRef] [PubMed]

73. Kobayashi, M.; Li, L.; Iwamoto, N.; Nakajima-Takagi, Y.; Kaneko, H.; Nakayama, Y.; Eguchi, M.; Wada, Y.; Kumagai, Y.; Yamamoto, M. The antioxidant defense system Keap1-Nrf2 comprises a multiple sensing mechanism for responding to a wide range of chemical compounds. Mol. Cell. Biol. 2009, 29, 493-502. [CrossRef] [PubMed]

74. Jones, R.M.; Desai, C.; Darby, T.M.; Luo, L.; Wolfarth, A.; Scharer, C.; Ardita, C.; Reedy, A.; Keebaugh, E.; Neish, A. Lactobacilli modulate epithelial cytoprotection through the Nrf2 pathway. Cell Rep. 2015, 12, 1217-1225. [CrossRef] [PubMed]

75. Zhang, D.D.; Lo, S.C.; Cross, J.V.; Templeton, D.J.; Hannink, M. Keap1 is a redox-regulated substrate adaptor protein for a Cul3-dependent ubiquitin ligase complex. Mol. Cell. Biol. 2004, 24, 10941-10953. [CrossRef] [PubMed]

76. Motohashi, H.; Yamamoto, M. Nrf2-Keap1 defines a physiologically important stress response mechanism. Trends Mol. Med. 2004, 10, 549-557. [CrossRef] [PubMed]

77. Zhang, D.D. Mechanistic studies of the Nrf2-Keap1 signaling pathway. Drug Metab. Rev. 2006, 38, 769-789. [CrossRef] [PubMed]

78. Klaassen, C.D.; Reisman, S.A. Nrf2 the rescue: Effects of the antioxidative/electrophilic response on the liver. Toxicol. Appl. Pharmacol. 2010, 244, 57-65. [CrossRef] [PubMed]

79. Maher, J.; Yamamoto, M. The rise of antioxidant signaling-The evolution and hormetic actions of Nrf2. Toxicol. Appl. Pharm. 2010, 244, 4-15. [CrossRef] [PubMed]

80. Wang, L.X.; Liu, K.; Gao, D.W.; Hao, J.K. Protective effects of two Lactobacillus plantarum strains in hyperlipidemic mice. World J. Gastroenterol. 2013, 19, 3150-3156. [CrossRef] [PubMed]

81. Gao, D.; Gao, Z.; Zhu, G. Antioxidant effects of Lactobacillus plantarum via activation of transcription factor Nrf2. Food Funct. 2013, 4, 982-989. [CrossRef] [PubMed]

82. Srivastava, S.K.; Yadav, U.C.; Reddy, A.B.; Saxena, A.; Tammali, R.; Shoeb, M.; Ansari, N.H.; Bhatnagar, A.; Petrash, M.J.; Srivastava, S.; et al. Aldose reductase inhibition suppresses oxidative stress-induced inflammatory disorders. Chem. Biol. Interact. 2011, 191, 330-338. [CrossRef] [PubMed]

83. Diao, Y.; Xin, Y.; Zhou, Y.; Li, N.; Pan, X.; Qi, S.; Qi, Z.; Xu, Y.; Luo, L.; Wan, H.; et al. Extracellular polysaccharide from Bacillus sp. strain LBP32 prevents LPS-induced inflammation in RAW 264.7 macrophages by inhibiting NF- $\mathrm{BB}$ and MAPKs activation and ROS production. Int. Immunopharmacol. 2014, 18, 12-19. [CrossRef] [PubMed]

84. Petrof, E.O.; Kojima, K.; Ropeleski, M.J.; Musch, M.W.; Tao, Y.; De Simone, C.; Chang, E.B. Probiotics inhibit nuclear factor- $\mathrm{KB}$ and induce heat shock proteins in colonic epithelial cells through proteasome inhibition. Gastroenterology 2004, 127, 1474-1487. [CrossRef] [PubMed]

85. Seth, A.; Yan, F.; Polk, D.B.; Rao, R.K. Probiotics ameliorate the hydrogen peroxide-induced epithelial barrier disruption by a PKC-and MAP kinase-dependent mechanism. Am. J. Physiol. Gastrointest. Liver Physiol. 2008, 294, G1060-G1069. [CrossRef] [PubMed]

86. Widmann, C.; Gibson, S.; Jarpe, M.B.; Johnson, G.L. Mitogen-activated protein kinase: Conservation of a three-kinase module from yeast to human. Physiol. Rev. 1999, 79, 143-180. [PubMed]

87. Kyriakis, J.M.; Avruch, J. Mammalian mitogen-activated protein kinase signal transduction pathways activated by stress and inflammation. Physiol. Rev. 2001, 81, 807-869. [PubMed]

88. Tao, Y.; Drabik, K.A.; Waypa, T.S.; Musch, M.W.; Alverdy, J.C.; Schneewind, O.; Chang, E.B.; Petrof, E.O. Soluble factors from Lactobacillus GG activate MAPKs and induce cytoprotective heat shock proteins in intestinal epithelial cells. Am. J. Physiol. Cell Physiol. 2006, 290, C1018-C1030. [CrossRef] [PubMed]

89. Blumberg, P.M. Complexities of the protein kinase C pathway. Mol. Carcinog. 1991, 4, 330-344. [CrossRef]

90. Stabel, S.; Parker, P.J. Protein kinase C. Pharmacol. Ther. 1991, 51, 71-95. [CrossRef]

91. Gopalakrishna, R.; Chen, Z.H.; Gundimeda, U. Modification of cysteine-rich regions in protein kinase C induced by oxidant tumor promoters and the enzyme specific inhibitors. Methods Enzymol. 1995, 252, 134-148. 
92. Lin, C.C.; Yang, C.C.; Wang, C.Y.; Tseng, H.C.; Pan, C.S.; Hsiao, L.D.; Yang, C.M. NADPH oxidase/ROS-dependent VCAM-1 induction on TNF- $\alpha$-challenged human cardiac fibroblasts enhances monocyte adhesion. Front. Pharmacol. 2015, 6, 310. [CrossRef] [PubMed]

93. Rahman, I.; Biswas, S.K.; Kode, A. Oxidant and antioxidant balance in the airways and airway diseases. Eur. J. Pharmacol. 2006, 533, 222-239. [CrossRef] [PubMed]

94. Lin, C.C.; Hsieh, H.L.; Shih, R.H.; Chi, P.L.; Cheng, S.E.; Chen, J.C.; Yang, C.M. NADPH oxidase 2-derived reactive oxygen species signal contributes to bradykinin-induced matrix metalloproteinase-9 expression and cell migration in brain astrocytes. Cell Commun. Signal. 2012, 10, 35. [CrossRef] [PubMed]

95. Lee, I.T.; Yang, C.M. Inflammatory signalings involved in airway and pulmonary diseases. Mediat. Inflamm. 2013, 2013. [CrossRef] [PubMed]

96. Aguirre, J.; Lambeth, J.D. Nox enzymes from fungus to fly to fish and what they tell us about Nox function in mammals. Free Radic. Biol. Med. 2010, 49, 1342-1353. [CrossRef] [PubMed]

97. Holmström, K.M.; Finkel, T. Cellular mechanisms and physiological consequences of redox-dependent signalling. Nat. Rev. Mol. Cell Biol. 2014, 15, 411-421. [CrossRef] [PubMed]

98. Bedard, K.; Krause, K.H. The NOX family of ROS-generating NADPH oxidases: Physiology and pathophysiology. Physiol. Rev. 2007, 87, 245-313. [CrossRef] [PubMed]

99. Gómez-Guzmán, M.; Toral, M.; Romero, M.; Jimenez, R.; Galindo, P.; Sanchez, M.; Zarzuelo, M.J.; Olivares, M.; Galvez, J.; Duarte, J. Antihypertensive effects of probiotics Lactobacillus strains in spontaneously hypertensive rats. Mol. Nutr. Food Res. 2015, 59, 2326-2336. [CrossRef] [PubMed]

100. Hussain, T.; Gupta, S.; Mukhtar, H. Cyclooxygenase-2 and prostate carcinogenesis. Cancer Lett. 2003, 191, 125-135. [CrossRef]

101. Schonbeck, U.; Sukhova, G.K.; Graber, P.; Coulter, S.; Libby, P. Augmented expression of cyclooxygenase-2 in human atherosclerotic lesions. Am. J. Pathol. 1999, 155, 1281-1291. [CrossRef]

102. Belton, O.; Byrne, D.; Kearney, D.; Leahy, A.; Fitzgerald, D.J. Cyclooxygenase-1 and -2-dependent prostacyclin formation in patients with atherosclerosis. Circulation 2000, 102, 840-845. [CrossRef] [PubMed]

103. Brzozowski, T.; Konturek, P.C.; Mierzwa, M.; Drozdowicz, D.; Bielanski, W.; Kwiecien, S.; Konturek, S.J.; Stachura, J.; Pawlik, W.W.; Hahn, E.G. Effect of Probiotics and Triple Eradication Therapy on the Cyclooxygenase (COX)-2 Expression, Apoptosis, and Functional Gastric Mucosal Impairment in Helicobacter pylori-Infected Mongolian Gerbils. Helicobacter 2006, 11, 10-20. [CrossRef] [PubMed]

104. Patel, B.; Kumar, P.; Banerjee, R.; Basu, M.; Pal, A.; Samanta, M.; Das, S. Lactobacillus acidophilus attenuates Aeromonas hydrophila induced cytotoxicity in catla thymus macrophages by modulating oxidative stress and inflammation. Mol. Immunol. 2016, 75, 69-83. [CrossRef] [PubMed]

105. Bondy, S.C.; Naderi, S. Contribution of hepatic cytochrome P450 systems to the generation of reactive oxygen species. Biochem. Pharmacol. 1994, 48, 155-159. [CrossRef]

106. Zangar, R.C.; Davydov, D.R.; Verma, S. Mechanisms that regulate production of reactive oxygen species by cytochrome P450. Toxicol. Appl. Pharmacol. 2004, 199, 316-331. [CrossRef] [PubMed]

107. Matuskova, Z.; Siller, M.; Tunkova, A.; Anzenbacherova, E.; Zacharova, A.; Tlaskalova-Hogenova, H.; Zidek, Z.; Anzenbacher, P. Effects of Lactobacillus casei on the expression and the activity of cytochromes P450 and on the CYP mRNA level in the intestine and the liver of male rats. Neuro Endocrinol. Lett. 2010, 32, 8-14.

108. Sharan, S. Intervention of Feeding Probiotic Dahi in Phase I and Phase II Pathway Activities of Xenobiotic Metabolism. Ph.D. Thesis, National Disease Research Interchange (NDRI), Karnal, India, 2009.

109. Costello, E.K.; Stagaman, K.; Dethlefsen, L.; Bohannan, B.J.M.; Relman, D.A. The application of ecological theory toward an understanding of the human microbiome. Science 2012, 336, 1255-1262. [CrossRef] [PubMed]

110. Mackie, R.I.; Sghir, A.; Gaskins, H.R. Developmental microbial ecology of the neonatal gastrointestinal tract. Am. J. Clin. Nutr. 1999, 69, 1035S-1045S. [PubMed]

111. Fanaro, S.; Chierici, R.; Guerrini, P.; Vigi, V. Intestinal microflora in early infancy: Composition and development. Acta Paediatr. 2003, 441, 48-55. [CrossRef]

112. Berg, R.D. The indigenous gastrointestinal microflora. Trends Microbiol. 1996, 4, 430-435. [CrossRef]

113. Penders, J.; Stobberingh, E.E.; van den Brandt, P.A.; Thijs, C. The role of the intestinal microbiota in the development of atopic disorders. Allergy 2007, 62, 1223-1236. [CrossRef] [PubMed] 
114. Rajilic-Stojanovic, M.; Smidt, H.; de Vos, W.M. Diversity of the human gastrointestinal tract microbiota revisited. Environ. Microbiol. 2007, 9, 2125-2136. [CrossRef] [PubMed]

115. Hsiao, W.W.; Metz, C.; Singh, D.P.; Roth, J. The microbes of the intestine: An introduction to their metabolic and signaling capabilities. Endocrinol. Metab. Clin. N. Am. 2008, 37, 857-871. [CrossRef] [PubMed]

116. Frank, D.N.; St Amand, A.L.; Feldman, R.A.; Boedeker, E.C.; Harpaz, N.; Pace, N.R. Molecular-phylogenetic characterization of microbial community imbalances in human inflammatory bowel diseases. Proc. Natl. Acad. Sci. USA 2007, 104, 13780-13785. [CrossRef] [PubMed]

117. Sekirov, I.; Russell, S.L.; Antunes, L.C.; Finlay, B.B. Gut microbiota in health and disease. Physiol. Rev. 2010, 90, 859-904. [CrossRef] [PubMed]

118. Jones, R.M.; Neish, A.S. Redox signaling mediated by the gut microbiota. Free Radic. Biol. Med. 2016. [CrossRef] [PubMed]

119. O'Toole, P.W.; Cooney, J.C. Probiotic bacteria influence the composition and function of the intestinal microbiota. Interdiscip. Perspect. Infect. Dis. 2008, 2008, 175285. [CrossRef] [PubMed]

120. Butel, M.J. Probiotics, gut microbiota and health. Méd. Mal. Infect. 2014, 44, 1-8. [CrossRef] [PubMed]

121. Bhardwaj, A.; Kaur, G.; Gupta, H.; Vij, S.; Malik, R.K. Interspecies diversity, safety and probiotic potential of bacteriocinogenic Enterococcus faecium isolated from dairy food and human faeces. World J. Microbiol. Biotechnol. 2011, 27, 591-602. [CrossRef]

122. Bhardwaj, A.; Malik, R.K.; Chauhan, P. Functional and safety aspects of enterococci in dairy foods. Indian J. Microbiol. 2008, 48, 317-325. [CrossRef] [PubMed]

123. Doron, S.; Gorbach, S.L. Probiotics: Their role in the treatment and prevention of disease. Expert Rev. Anti-Infect. Ther. 2006, 4, 261-275. [CrossRef] [PubMed]

124. Alvarez-Olmos, M.I.; Oberhelman, R.A. Probiotic agents and infectious diseases: A modern perspective on a traditional therapy. Clin. Infect. Dis. 2001, 32, 1567-1576. [CrossRef] [PubMed]

125. Silva, M.; Jacobus, N.V.; Deneke, C.; Gorbach, S.L. Antimicrobial substance from a human Lactobacillus strain. Antimicrob. Agents Chemother. 1987, 31, 1231-1233. [CrossRef] [PubMed]

126. Vanderhoof, J.A.; Young, R.J. Current and potential uses of probiotics. Ann. Allergy Asthma Immunol. 2004, 93, S33-S37. [CrossRef]

127. Cani, P.D.; Delzenne, N.M. Interplay between obesity and associated metabolic disorders: New insights into the gut microbiota. Curr. Opin. Pharmacol. 2009, 9, 737-743. [CrossRef] [PubMed]

128. Qiao, Y.; Sun, J.; Ding, Y.; Le, G.; Shi, Y. Alterations of the gut microbiota in high-fat diet mice is strongly linked to oxidative stress. Appl. Microbiol. Biotechnol. 2013, 97, 1689-1697. [CrossRef] [PubMed]

129. Xin, J.; Zeng, D.; Wang, H.; Ni, X.; Yi, D.; Pan, K.; Jing, B. Preventing non-alcoholic fatty liver disease through Lactobacillus johnsonii BS15 by attenuating inflammation and mitochondrial injury and improving gut environment in obese mice. Appl. Microbiol. Biotechnol. 2014, 98, 6817-6829. [CrossRef] [PubMed]

130. Park, D.Y.; Ahn, Y.T.; Park, S.H.; Huh, C.S.; Yoo, S.R.; Yu, R.; Sung, M.K.; McGregor, R.A.; Choi, M.S. Supplementation of Lactobacillus curvatus HY7601 and Lactobacillus plantarum KY1032 in diet-induced obese mice is associated with gut microbial changes and reduction in obesity. PLoS ONE 2013, 8, e59470. [CrossRef] [PubMed]

131. Everard, A.; Matamoros, S.; Geurts, L.; Delzenne, N.M.; Cani, P.D. Saccharomyces boulardii administration changes gut microbiota and reduces hepatic steatosis, low-grade inflammation, and fat mass in obese and type 2 diabetic $\mathrm{db} / \mathrm{db}$ mice. mBio 2014, 5, e01011-e01014. [CrossRef] [PubMed]

132. Xue, L.; He, J.; Gao, N.; Lu, X.; Li, M.; Wu, X.; Liu, Z.; Jin, Y.; Liu, J.; Xu, J.; Geng, Y. Probiotics may delay the progression of nonalcoholic fatty liver disease by restoring the gut microbiota structure and improving intestinal endotoxemia. Sci. Rep. 2017, 7, 45176. [CrossRef] [PubMed]

133. Klaenhammer, T.R.; Kleerebezem, M.; Kopp, M.V.; Rescigno, M. The impact of probiotics and prebiotics on the immune system. Nat. Rev. Immunol. 2012, 12, 728-734. [CrossRef] [PubMed]

(C) 2017 by the authors. Licensee MDPI, Basel, Switzerland. This article is an open access article distributed under the terms and conditions of the Creative Commons Attribution (CC BY) license (http:/ / creativecommons.org/licenses/by/4.0/). 